Please cite as

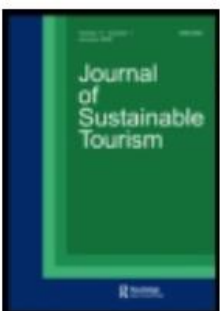

(1) CrossMark

Original Articles

The influence of the political environment and destination governance on sustainable tourism development: a study of Bled, Slovenia

DOI: $10.1080 / 09669582.2015 .1134557$

Tanja Mihalič ${ }^{a^{*}}$, Tina Šegota ${ }^{a}$, Ljubica Knežević Cvelbar ${ }^{a}$ \& Kir

Kuščer $^{\mathrm{a}}$

Publishing models and article dates explained

Received: 10 Sep 2014

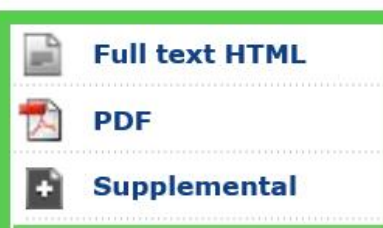

Full access

Accepted: 14 Dec 2015

Published online: 01 Apr 2016

Please check if the paper has already been published in a printed journal JOST.

RESEARCH ARTICLE

The Influence of the Political Environment and Destination Governance on Sustainable Tourism Development: The Case of Bled, Slovenia

Tanja Mihalič ${ }^{1}$, Tina Šegota ${ }^{2}$, Ljubica Knežević Cvelbar ${ }^{3}$ and Kir Kuščer ${ }^{4}$

${ }^{a}$ Faculty of Economics, University of Ljubljana, Ljubljana, Slovenia

${ }^{I}$ Tel.+38615892 496; tanja.mihalic@ef.uni-lj.si

${ }^{2}$ Tel. +38615892 511; tina.segota@ef.uni-lj.si

${ }^{3}$ Tel. +386 15892 497; ljubica.knezevic@ef.uni-lj.si

${ }^{4}$ Tel.+38615892 750; kir.kuscer@ef.uni-lj.si 
Tanja Mihalič, $\mathrm{PhD}$, is a full-time professor of tourism at the Faculty of Economics, University of Ljubljana and the head of its Tourism Institute. Her research interests include tourism economics, environmental economics, policy and sustainable tourism development. She is a member of the UN WTO World Committee on Tourism Ethics and member of the executive body of the International Association of Tourism Economics (IATE).

Tina Šegota is a teaching assistant and $\mathrm{PhD}$ candidate at the Faculty of Economics, University of Ljubljana. Her research interests include seasonality, sustainable tourism development, tourism impacts on the quality of life, and advertising and consumer behaviour in tourism.

Ljubica Knežević Cvelbar, $\mathrm{PhD}$, is an associate professor at the Faculty of Economics, University of Ljubljana, and a visiting professor at numerous universities around the world. She has been involved in more than 30 research projects, including ones involving EU funds and UNDP grants. She has published more than 20 papers in refereed tourism journals. She is also the co-author of more than 10 chapters in books. Her research interests include tourism economics, sustainable tourism development and tourism marketing.

Kir Kuščer, PhD, is a teaching assistant at the Faculty of Economics, University of Ljubljana (FELU). His research interests include mountain tourism, destination management, sport tourism and innovation in tourism. The FELU is currently a partner in the INTERREG IVC project (Digital Agenda for a New Tourism Approach in European Rural and Mountain Areas), where he is the project leader.

Acknowledgements. An earlier version of this paper was given at the BEST EN conference held in the Faculty of Economics, University of Ljubljana, Slovenia, in July 2014.

\section{The Influence of the Political Environment and Destination Governance on Sustainable Tourism Development: a study of Bled, Slovenia}

\section{Introduction}

Sustainable tourism destination development has attracted considerable attention from researchers for many years, especially about the positive and negative impacts of tourism on destination resources and communities. Tourism can bring positive and negative impacts to communities, but tourism development can also depend on how the residents of a destination perceive these impacts. As explained by social exchange theory and previous research, destination residents' develop their support for tourism based on their satisfaction with their 
life in the tourism-affected community (Dyer, Gursoy, Sharma, \& Carter, 2007; VargasSánchez, de los Ángeles Plaza-Mejía, \& Porras-Bueno, 2009).

In the above context, destination resources have commonly been understood as economic, socio-cultural and natural (or environmental, in a narrower meaning), which corresponds to the so-called three-pillar sustainable tourism concept (UNEP \& WTO, 2005).

However, researchers should distinguish between the theoretical concept of the threepillars of sustainable tourism (UNEP \& WTO, 2005) and its practical implementation in tourism (Mihalič, 2016). The literature shows a gap between the conceptual understanding of sustainable tourism development and the implementation of tourism sustainability. Wheeler (1993) argued that the intellectually appealing concept of sustainable tourism had little practical application, while Higgins-Desbiolles (2010) states that its practical implementation remains difficult. It seems that this problem could be reduced if the three-pillar sustainability concept is expanded to include some of the 'enablers' of efficient sustainability implementation used in business and destination practices. Many authors have discussed additional requirements for the implementation of sustainability, such as political support, power, critical mass, consensus, environmental education, awareness and ethics (Mihalič, Žabkar, \& Knežević Cvelbar, 2012; Ritchie \& Crouch, 2003; UNWTO, 2004). Ritchie and Crouch (2003) pointed out the need to extend the sustainable tourism debate with political sustainability. Recently, some of these 'enablers' have been debated under the destination governance theme, which is interested in how tourism destinations steer and govern the process of implementing (as well as planning and controlling) sustainable tourism development (Beritelli, 2011).

However, previous studies have shown little interest in studying sustainable tourism development with respect to residents' attitudes to tourism and the political dimensions of its 
governance (Jurowsky \& Gursoy, 2004). This paper addresses that issue and contributes to understanding the political environment surrounding sustainable tourism's implementation.

This paper is composed of eight sections. After the Introduction, the first three sections set the theoretical context of how resident satisfaction and support for tourism are impacted by resident perceptions of tourism through the three-pillar sustainability concept, and explore the roles of the political environment and destination governance. A conceptual model and hypotheses are then presented followed by a section that describes the characteristics of the place where the survey was conducted, the destination of Bled, in Alpine Slovenia. A section on methodology and the data collection follows. The paper then continues with analysis and research findings on the political environment and resident support for tourism development, followed by a discussion and conclusion section.

To be consistent with the current literature, this paper uses the term environment both narrowly and broadly. The first use refers to the natural environment only as tourism literature often uses environmental as a synonym for natural (UNWTO, 2004). The second use refers to any kind of environment, such as natural, economic, technological or political etc. (Mihalič \& Kaspar, 1996; Ritchie \& Crouch, 2003). Further, with regard to the sustainability debate, the notion of sustainability pillars refers to the original three pillars only: economic, natural (or environmental, narrower meaning) and socio-cultural (UNWTO, 2004). The term political environment has only been used in a few tourism studies (Mihalič \& Kaspar, 1996; Ritchie \& Crouch, 2003) and, as such, is not widely used in the tourism literature. As our understanding of the political environment (an older term) overlaps with the emerging understanding of destination governance (a newer term) (Beritelli, 2011; Bramwell \& Lane, 2011), both terms are discussed in the paper.

\section{Literature research}




\section{Residents' perception of tourism impacts}

Numerous studies have analysed resident reactions to the local development of tourism since the early writings of Doxey (1975). They have all shown that tourism has an impact on the economic, natural and socio-cultural environments of the host communities (Andereck, Valentine, Knopf, \& Vogt, 2005; Bujosa Bestard \& Rosselló Nadal, 2007a; Nunkoo \& Ramkissoon, 2010; Vargas-Sánchez, Porras-Bueno, \& de los Ángeles Plaza-Mejía, 2011). Moreover, in the work of Easterling (2004), Harill (2004) and Deery, Jago, and Fredline (2011) and, more recently, Nunkoo, Smith, and Ramkissoon (2013) and Sharpley (2014), there is a comprehensive body of research about the positive and negative effects of tourism in host communities.

One commonality of these studies is that the research on positive and negative tourism impacts evolved from the conceptual understanding of sustainable tourism development (UNWTO, 2004). In this context, sustainable development is understood as the three-pillar concept that refers to the economic, natural and socio-cultural environment. Sharpley (2006) argues that sustainable development achieves, among others, a "balance between the tourism environment..." and “...the needs of local communities..." (p. 109). It is concerned with providing opportunities to enhance economic growth, protect locations and improve the quality of life of residents while enhancing opportunities for the future through the coexistence of tourism development and environmental quality (Eagles, McCool, \& Haynes, 2002).

However, not all environments have been given equal academic and practical attention. Research often focuses on the economic or environmental pillars only, which might provide an incomplete picture of community concerns (Harrill, 2004; Nunkoo et al., 2013; Sharpley, 2014). Further, the literature offers many contradictory findings. For illustration, Dyer et al. (2007) found that perceived economic and cultural positive impacts of tourism have a 
significant impact on resident support for tourism development, whereas the perception of the impacts on the natural environment were downplayed relative to the economic and cultural environment. Research findings by Stylidis and Terzidou (2014) agree with Dyer's et al. findings on the first two pillars, yet differed from their findings on the natural environment, which proved to have a significant influence on how much residents supported tourism. This is in line with Brida, Disegna and Osti (2011) where their findings revealed that resident perceptions of the environmental, economic and socio-cultural impacts of tourism affected their level of support.

One criticism of this approach is that the full spectrum of common tourism impacts should be considered (Nunkoo \& Ramkissoon, 2012; Stylidis \& Terzidou, 2014). In this context, the three-pillar sustainability concept offers a well-structured framework for studying positive and negative tourism impacts in all three environments: economic, natural and sociocultural.

For the economic pillar, different indicators may be used to measure the diverse economic impacts; for example, indicators such as employment, the standard of living, investments, improvement of a town's tax revenue, a price increase of goods and services, infrastructure development, development of other industries in the area (Ko \& Stewart, 2002; Lee, 2013; Nunkoo \& Ramkissoon, 2011; Stylidis \& Terzidou, 2014). Most studies (Andereck \& Voght, 2000; Brida et al., 2011; Jurowsky, Uysal, \& Williams, 1997) showed that resident perceptions of economic impacts have a positive effect on support for tourism, where more positive perceptions result in support and negative perceptions result in opposition.

With regard to the environmental pillar, tourism is mostly held responsible for pollution (litter, water, air, noise) and the destruction of the natural environment (Andereck et al., 2005; Bujosa Bestard \& Rosselló Nadal, 2007b; Ko \& Stewart, 2002). To evaluate environmental 
impacts the literature suggests indicators such as preservation of the environment, landscape appearance improvement, air, water and waste pollution, green area destruction, and ecological awareness (Andereck et al., 2005, Andereck et al. 2007; Bujosa Bestard \& Roselló Nadal, 2007b). As evident from the studies by Chen (2001), Yoon, Gursoy, and Chen (2001), and Stylidis and Terzidou (2014), perceived tourism impacts on the natural environment (if used to denote pollution and noise) are positively related to opposition to tourism.

Thirdly, the socio-cultural environment pillar is commonly examined as one entity since tourism impacts on both the social and cultural environment overlap to a large extent (Wall \& Mathieson, 2006). It has been suggested to measure the socio-cultural impacts of tourism by observing indicators of the availability and development of public utilities, shopping, restaurant and entertainment opportunities, and parks and recreational areas, encouraging the production and sales of local products and business opportunities for local people, the quality of education and public services, encouragement of cultural activities, exploitation of local natives, crowding, traffic congestion, crime, preservation of local culture, host-tourist conflicts, and the over-commercialisation of historical attractions (Dyer et al., 2007; Nunkoo \& Ramkissoon, 2012; Teye, Sirakaya \& Sönmez, 2002). As in case of the previous two environments, positive perceptions of tourism impacts on the socio-cultural environment are positively related to tourism support.

\section{Residents' satisfaction and support for tourism}

In the context of social exchange theory when applied to residents' attitudes to tourism, the majority of studies refer to tourism impacts and support for tourism, while some studies have also incorporated satisfaction with tourism or quality of life in a tourism destination (Ko \& Stewart, 2002; Nunkoo \& Ramkissoon, 2011; Perdue, Long, \& Kang, 1999; Vargas-Sánchez et al., 2009). 
In order to operationalise resident satisfaction, the literature suggests surveying residents' overall satisfaction with the quality of life in a destination, satisfaction with living conditions such as recreational opportunities for locals, and the destination's desirability as a place to live. More specifically, possible measurement statements could relate to how proud the residents are to live in a well-known tourism destination, whether they suffer from living in the tourist destination, and their intention to move away from the destination because of their suffering (Nunkoo \& Ramkissoon, 2011; Perdue et al., 1999).

Resident support for tourism development has been operationalised by indicators such as support of tourism's economic role, development priority over other industries, the annual visitation increase, and a general evaluation of positive impacts over negative ones (Nunkoo \& Ramkissoon, 2011; Nunkoo, Ramkissoon, \& Gursoy, 2012; Stylidis \& Terzidou, 2014).

\section{The political environment and destination governance}

In this study, use of the term political environment does not refer to political parties or systems (although both might be relevant to tourism development), but instead to political power, leadership, structures, mechanisms and strategies or policies for the implementation of sustainable tourism development. The notion of a political environment has been expanded by some authors as a further development of the three environments (or pillars) of the sustainability debate (ECETAT \& ECOTRANS, 2004; Mihalič, 2009; Mihalič et al., 2012; Ritchie \& Crouch, 2003). Contrary to the relative consensus on the three-pillar meaning of sustainable development, the notion of political environment has not yet been so strongly established, and its nomination as the missing element has not yet reached consensus amongst the tourism academic community. More specifically, in 2004 one study extended sustainable tourism implementation monitoring with indicators of the political implementation of the 
sustainability concept (ECETAT \& ECOTRANS, 2004). Ten years later, another sustainability monitoring study $(\mathrm{EC}, 2014)$ suggested extending the three-pillar-based indicators scheme with a destination management element, trying to capture - among others - the role of local governance and strategic planning. Later, the discussion on tourism destination governance captured some elements from our understanding of the political environment (Beritelli, 2011) by focusing on how tourism destinations steer and govern the process of planning, implementing and controlling sustainable tourism development (Beritelli, 2011; Bramwell \& Lane, 2011) .

It is important to stress that the political dimension is of a different nature (Mihalič et al., 2012) to the other three pillars of sustainability. The latter refer to tourism impacts, and the political element is defined more as a necessary requirement for the implementation of sustainable strategies. Thus, the political environment refers to coordination and cooperation among numerous actors in order to develop and apply policies for tourism, as these are all key features of governance. Where there is effective governance, destinations are more likely to be successful in developing sustainable tourism (Bramwell, 2011). According to Butler (2010), effective governance usually stands for having good mechanisms for the successful coordination of collective actions. Thus, sustainable development depends on the ability to ensure cooperation and coordination among diverse stakeholders, which often have divergent interests, beliefs and priorities (Bramwell, 2011; Bramwell \& Lane, 2000). This creates an initial difficulty when it comes to the governance of sustainable tourism since it poses a tremendous challenge to find a balance among stakeholders, which are usually vertically and horizontally dispersed over the national, regional and local organisational levels as well as across many different sectors and policy domains (Bramwell, 2011). Moreover, the second difficulty with the proper governance of sustainable tourism is the need to integrate sustainable policies that acknowledge the socio-cultural, natural and economic environmental aspects of 
policy development (Hall, 2008).

When it comes to tourism governance within the community, for many destinations the local government has roles of informing local residents about the development of tourism in the community, further involving them in the planning process, decisions on specific requests for development permission, and ensuring a fair representation of the community's quality of life in the tourism development strategy. Moreover, when it comes to sustainable tourism development an important driver is the community's ability to influence local policy decisions (Nunkoo \& Ramkissoon, 2011; Thibaut \& Kelley, 1959; Wrong, 1979). These studies showed that community support for tourism development depends on its power to influence tourism development. Lee (2013) also revealed that a higher degree of community involvement in the development of sustainable tourism leads to higher support for tourism. On the other hand, Boley, McGehee, Perdue, and Long (2014) found that support for tourism was not directly impacted by residents' perception of their power to influence tourism development. These perplexing results only support our comment that the political dimension needs more research and testing.

Within the context of the sustainable tourism development debate, common ground has been found between the political environment and destination governance. More specifically, we define destination governance as a destination's adaptation to the economic, socio-cultural and natural environment with respect to its operations by involving all stakeholders and effectively managing their relationships. In this setting, governance represents a broader, yet in many respects a similar concept compared to our political environment. Both concepts are 'enablers' of the implementation of sustainable tourism development and cover some important issues such as cooperation among different stakeholders, consensus and fulfilment of their interests. The assurance of the presence of a proper strategic framework as well as a policy to 
maintain and further develop the quality and harmony of a community's life in general are certainly some key issues that relate to effective and successful sustainable tourism development/implementation.

\section{Conceptual model and hypotheses}

In order to study perceptions about tourism, many researchers have used structural modelling approach (Gursoy, Jurowski, \& Uysal, 2002; Gursoy, \& Rutherford, 2004; Dyer, Gursoy, Sharma, \& Carter, 2007)). Our structural model is based on the research presented above, taking two relevant observations into account. First, the relations between resident satisfaction and support for tourism have not been well addressed by existing research and, second, so far the missing enabler of sustainability, i.e. the political environment, has not been studied at all in the context of sustainable tourism development. Thus, we incorporated both observations in our proposed model of the relationship between the tourism pillars and resident support for tourism development (Figure 1) and developed the corresponding hypotheses:

\section{(Insert Figure 1 about here)}

Figure 1. Theoretical model, direct and indirect paths.

We assume that the level of residents' satisfaction with tourism development has a direct impact on their support for tourism (H1).

Then, in line with the three-pillar definition of sustainable development, we assume that the more residents perceive that tourism has a positive impact on their socio-cultural $(\mathrm{H} 2 \mathrm{a})$, 
natural $(\mathrm{H} 2 \mathrm{~b})$ and economic environment $(\mathrm{H} 2 \mathrm{c})$, the more satisfied they would be with tourism development in their community.

In order to test the new role of the political environment, we then hypothesise that residents' perceptions of the political environment have a direct impact on the socio-cultural (H3a), natural (H3b) and economic environment (H3c). In addition, we assume some indirect connections. We argue that perceptions of the political environment indirectly impact resident satisfaction with tourism development through the socio-cultural (H4a), natural (H4b) and economic environment $(\mathrm{H} 4 \mathrm{c})$.

\section{Bled: the tourism destination}

Located in the north-western region of Slovenia, the Municipality of Bled is home to more than 8,200 inhabitants and accommodates more than 600,000 overnight stays during the year (SORS, 2014). Bled's main attractions are its beautiful landscape, attractive glacial lake and an impressive castle perched on a rock above the lake, which alone accounts for more than 200,000 visitations per year (SORS, 2014).

The beginnings of tourism development date to 1855. A Swiss hydropath named Arnold Rikli recognised the value of Bled's climate and lake. He built necessary tourism infrastructure and introduced a new natural method of treatment, based on bathing, sunbathing, walks and modest, primarily vegetarian, eating. In addition to Rikli's patients, Bled attracted more and more people who wanted to spend their holidays in a healthy and above all beautiful environment. In 1870, Bled got its railway station, at which express trains stopped. In 1903, Bled received the Gold Medal at a large international exhibition of spas in Vienna, and in 1906, it was officially classified amongst the important tourist spots in Imperial Austria. Nowadays, 
Bled is one of the most important tourist destinations in Slovenia and it continues to attract tourists and one-day visitors, due to its proximity to the Slovenian capital Ljubljana.

Bled's attractiveness has been recognised by National Geographic Traveller as it was featured on the magazine's double-issue cover in 2011, by the UK's leading lifestyle magazine Food and Travel in 2011, and in Lonely Planet in 2013 (SPIRIT Slovenia, 2011). Its tourism is primarily based on summer visitations. An increased amount of winter tourism correlates with cultural events and skiing, which bring 40,000 visitors to the Straža ski slope (SORS, 2014). Bled has 3,064 hotel beds in 36 three- to five-star hotels, 1,621 beds in private accommodation establishments and 1,195 bed places in camps (SORS, 2014).

Since 1879 there were various tourism organizations in Bled responsible for tourism promotion, organization of events, providing information and coordination. Tourism Association Bled, a representative of civil society, was established 135 years ago. Local Municipality always had competences in tourism development. Destination management organizations, based on a public - private partnership, in Slovenia known as Local Tourism Organizations (LTOs), become relevant in the 1990ss. The LTO's are financed from the governmental sources and associated with local and national politics in the country. The LTO'smain tasks include the development, planning and management of tourism activities in order to achieve its strategic goals. The overall development strategy for Bled for 2009 to 2020 (Municipality of Bled, 2009) emphasises the need to develop Bled into a green Alpine community for local residents and an attractive destination for visitors. It considers the preservation of its nature and water quality along with established traffic regulations to reduce congestion, parking space problems and air pollution. It also foresees the development of innovative and dynamic visitor-friendly content for Bled's cultural, historical and recreational attractions. Besides that, tourism is seen as a means to increase the quality of life of local 
residents since it improves public services while providing more public spaces as well as recreational and business opportunities for local residents.

\section{Data collection and methodology}

The survey was conducted between 31 January and 2 April 2014. The self-administered questionnaire was distributed to Bled's residents. The distribution was conducted through both the local newspaper and electronic sources. Newspapers containing the questionnaire were sent to each occupied household that could be identified (3,328 households in total). In the case of multiple-family residents, each residential unit was considered a household. Residents were asked to complete the questionnaire and return it to the municipality in a sealed envelope or online. Overall, 329 questionnaires were returned.

To develop our measurement instrument, we firstly created a list of sustainable tourism development indicators based on the literature review. The list initially included over 200 indicators. Those indicators were evaluated using the three-round Delphi methodology. The expert group consisted of academia and local industry representatives. Delphi experts reduced the initial list of indicators to 37 that were used in the subsequent survey. A copy of the survey can be found in Figure A in the Supplemental Data available on the web based version of this paper. All indicators were designed as statements that we asked the respondents to evaluate on a seven-point Likert scale, ranging from Strongly Disagree (1) to Strongly Agree (7). We concluded the study with demographic questions about the respondents.

The collected data were analysed with Principal Component Analysis (PCA) to reduce the number of variables in the model. The correlation matrix was then checked to reveal any possibly problematic variables. After this data-reduction procedure, only 23 indicators were used in the further analysis (see Table 2). Thus, a six-factor model was then inputted into the 
Confirmatory Factor Analysis (CFA) and, finally, Structural Equation Modelling was used to establish the connections between the factors.

\section{Analysis of residents' support for tourism development in Bled}

\section{Sample characteristics}

Table 1 presents selected demographic characteristics of the sample and its population. Our sample is representative according to age $\left(\chi^{2}=6.691, \mathrm{df}=4, \mathrm{p}>0.05\right)$, employment in tourism $(\chi 2=0.068, \mathrm{df}=1, \mathrm{p}>0.05)$ and location of residency within the Municipality of Bled $(\chi 2=4.046, \mathrm{df}=4, \mathrm{p}>0.05)$

\section{(Insert Table 1 about here)}

Table 1. Sample and representativeness tests

\section{Results}

Initially, PCA was performed on the six factors (composed of 37 variables) to reduce the number of variables used in the subsequent CFA; 28 variables were retained (three from the political environment, seven from the socio-cultural environment, six from the natural environment, four from the economic environment, four from residents' satisfaction with tourism and four from residents' support for tourism). When the correlation matrix for the whole model was analysed, four variables (one from the economic environment, two from the natural environment and one from residents' support for tourism development) were excluded 
from further analysis due to the low inter-item and item-to-total correlations on one hand and too high correlations with variables from other factors on the other (Hair, Black, Babin, \& Anderson, 2010). At this stage, two variables of the satisfaction construct, namely "Because of tourism I would like to move out of Bled" and "I suffer from living in a tourism destination", were reverse-coded in order to provide a consistent factor (i.e. positive). After the PCA and correlation matrix analysis, the reliability of the factors was checked with Cronbach's alpha, which ranged from 0.59 to 0.87 . The lowest Cronbach alpha is that for residents' support for tourism development, which is below the suggested minimum of 0.6 (Hair et al., 2010). Therefore, further reliability analysis was conducted. The 24-variable, six-factor theoretical measurement model was then tested for consistency with a CFA. The analysis shows that the Squared Multiple Correlations (SMCs) suggest good indicator reliability. On the other hand, convergent validity of all constructs is not guaranteed since the residents' support for the tourism development construct's Composite Reliability $(\mathrm{CR}=0.66)$ and Average Variance Extracted (AVE=0.41) are both below the recommended thresholds of 0.7 and 0.5 , respectively (Hair et al., 2010). When also taking into consideration Cronbach's alpha coefficient for this construct and Hair et al.'s (2010) suggestion that the reliability of a construct will improve if the item with the lowest loading is removed, we decided to eliminate the variable "The number of tourists visiting Bled should increase annually" from the model. Before running the analysis again, the loadings of the items about the residents' support for tourism construct were set to be equal. This was done in accordance with Kenny, Kashy \& Bolger (1998) who state that two variables per construct are sufficient provided the loadings are set to be equal and thus ensure identification. Further, Hair et al. (2010) also state that any model with a two-variable construct is identified provided that each construct has a relationship with some other construct.

The SMCs suggest good indicator reliability (Table 2). Moreover, the CRs of the constructs provide further proof of convergent reliability of the measurement model. Although 
CR for residents' support for tourism development is below the generally agreed limit of 0.7 , Hair et al. (2010) state that the value of 0.68 is still acceptable provided that the other indicators of a construct's validity are good (AVE of residents' support for tourism development is 0.52 ). Other AVEs range from 0.48 to 0.53 , and since other CRs (except for residents' support for tourism development) are well above 0.7 , the convergent validity of the constructs is ensured.

\section{(Insert Table 2 about here)}

Table 2. Descriptive statistics and measurement model results

Finally, Structural Equation Modelling was undertaken to test the hypothesised relationships between the factors. The resulting structural model provides strong evidence for the proposed relationships between the constructs and their indicators. The chi-square statistic was found to be highly significant but sensitive to the sample size so a more appropriate statistic is the relative chi-square $(\chi 2 / \mathrm{df})$, which indicates a good overall model fit. Other measures provide evidence of a moderate model fit (see the note below Figure 2).

SEM confirms the connections among the perceived impacts of the sustainability pillars, the political environment and residents' satisfaction and support for tourism development. All constructs are relatively well explained by their predictors as suggested by the explained variance, which ranges from 0.16 to 0.74 . The only problematic construct is the natural environment, whose sole predictor is the political environment and its explained variance is just 0.02. However, the path coefficient between the two constructs is still significant; besides, the focus of our analysis is not to explain the natural environment but 
residents' satisfaction and support for tourism development, both of which have a very high amount of explained variance (0.48 and 0.74, respectively) (Table 2).

Further analysis of the structural part of the model reveals that the political environment has a direct impact on two out of the three sustainability pillars - the natural and socio-cultural environments. A direct connection with the economic environment was not statistically confirmed. Nevertheless, the political environment is a strong force in shaping the residents' satisfaction levels with tourism through the socio-cultural and natural environments. In addition, the economic environment also affects a resident's satisfaction level with tourism, which in turn affects that resident's support for tourism (Figure 2).

\section{(Insert Figure 2 about here)}

Figure 2. The model of residents' support for tourism

The indirect effects were investigated by conducting a series of mediation tests (Figure 3). For a construct to act as a mediator, three conditions must be fulfilled. The paths from the independent construct to the mediator and from the mediator to the dependent construct must be significant, while the introduction of a mediator must also lower the path loading between the independent and dependent construct. If the direct path loading is not significant, the effect is fully mediated. If it is, then the mediator has a partial effect (Baron \& Kenny, 1986). The political environment was seen to affect the natural and socio-cultural environments which, in turn, affect the residents' level of satisfaction with tourism. But when the natural and sociocultural environments were removed from the model, the formerly non-significant direct path from political environment to resident satisfaction with tourism $(\gamma=0.17)$ became significant: 
$\gamma=0.47(p<0.001)$ with the removal of the socio-cultural environment, and $\gamma=0.25(p<0.001)$ with the removal of the natural environment. The relationship between the political environment and a resident's satisfaction with tourism is thus fully mediated by both the sociocultural and natural environment. On the other hand, the political environment does not have a statistically significant direct impact on the economic environment. Therefore, the latter cannot play a mediating role between the political environment and a resident's satisfaction. However, in relation to the economic environment there is an indication of another indirect connection, which has not been hypothesised (Figure 1). It would seem that the political environment affects the natural environment $(\gamma=-0.14, \mathrm{p}<0.05)$ which, in turn, affects the economic environment $(\beta=0.39, \mathrm{p}<0.001)$. When the natural environment is removed from the model, the formerly non-significant direct path from the political to the economic environment then becomes significant $(\gamma=-0.16, p<0.05)$. Therefore, the natural environment fully mediates the relationship between the political and economic environment.

\section{(Insert Figure 3 about here)}

Figure 3. Empirical model, mediation effects

\section{Discussion}

Our empirical study confirmed a total of 23 indicators that created a six-factor model in line with our theoretical model construct (Table 2). More specifically, these factors were the political environment, the three pillars of sustainable tourism development (socio-cultural, natural and economic), residents' satisfaction and support for tourism. Each of these represents a self-standing construct in our model. 
This paper has aimed to contribute to the tourism knowledge base by integrating a new dimension - the political environment - into sustainability models that survey community support for tourism. Thus, our proposed model and analysis started with and focused mainly on the political environment which was measured by three indicators: support from the local tourism institution, residents' involvement in the planning of tourism development and the existence of a strategic approach to residents' quality of life. Then, our model analysed the direct and indirect impacts of the political environment on the other factors. It was concluded that Bled's residents perceive the political environment as the least developed as they gave low values to its elements. On a seven-point Likert scale, the political environment was evaluated with the lowest mean value (2.95), which may reflect its relatively low development measured through the perception of its residents. According to the respondents, a resident's involvement in tourism development (mean 2.86) and support from the local tourism organisation (mean 2.95) can be significantly improved. Residents were seen to be more positive about their community's development strategy and its sustainable tourism orientation (mean 3.05). However, despite its low average evaluation the political environment factor has relatively high composite reliability, revealing the construct's high level of internal consistency. Further, residents' support for tourism and satisfaction received high mean values (5.91 and 5.72, respectively). One could speculate that further development of the (at present) relatively weak political environment would result in even higher satisfaction and support for tourism development in Bled.

With respect to the impact of Bled's political environment on the other factors, seven direct and three indirect connections were originally hypothesised. The first hypothesis (H1), which proposed a direct relationship between residents' satisfaction with tourism and support for tourism development, was substantiated. It was found that residents' satisfaction with tourism had a significant impact $(\beta=0.73, \mathrm{p}<0.001)$. Indeed, instead of simply assuming that 
positive attitudes would mean positive support for tourism development we advanced our study by measuring support with two different indicators (Table 2). In CFA (Table 2) coherent factor support (mean 5.91) was created, showing that residents support the development of tourism over other industries (mean 5.63), and support tourism and its economic role (mean 6.19). Among all indicators, Bled's residents perceive the economic role of tourism as the most important and graded it with the highest grade (Table 2, mean 6.19 on a 7-point Likert scale).

By forming separate factors with CFA, this study verified that in our real case destination tourism impacts may be grouped into the socio-cultural, natural and economic environment (Jurowski et al., 1997; Stylidis \& Terzidou, 2014; Yoon et al. 2001). On one hand, the respondents gave a relatively high score to natural and economic negative impacts (Table 2 , means of 4.27 and 4.32, respectively). On the other hand, the positive socio-cultural impacts were scored with a mean value of 4.30. Waste pollution and economic overdependence on tourism constituted $60 \%$ of the negative responses, whereas the tourist industry's ability to provide more business for local people was primarily seen as positive by more than $90 \%$ of local residents. Each of the three environments impacts a resident's satisfaction with the development and presence of tourism in the destination.

Therefore, it is assumed that the more tourism is seen to be benefiting the socio-cultural $(\mathrm{H} 2 \mathrm{a})$, natural $(\mathrm{H} 2 \mathrm{~b})$ and economic environment $(\mathrm{H} 2 \mathrm{c})$ the more residents will be satisfied and embrace tourism in their communities, and vice versa.

At first, the strongest factor was seen to be the impact of the socio-cultural environment $(\mathrm{H} 2 \mathrm{a}, \beta=0.58, \mathrm{p}<0.001)$. Residents were observed to be the most happy with tourism's ability and power to protect the local culture (mean 4.57), improve public services (mean 4.44) and provide more public spaces and recreational opportunities for locals (mean 4.13). Second, perceptions of a negative environmental impact reduced the residents' satisfaction with tourism 
$(\mathrm{H} 2 \mathrm{~b}, \beta=-0.18, \mathrm{p}<0.01)$. Among all of the negative impacts, waste pollution and water pollution were seen to be the most important (means of 4.81 and 4.77 , respectively). Third, a resident's negative perception of the economic impact of tourism also reflected negatively on their satisfaction levels $(\mathrm{H} 2 \mathrm{c}, \beta=-0.15, \mathrm{p}<0.001)$. The issues of concern are overdependence on tourism (mean 4.84), the prioritisation of tourism over other industries (mean 4.04) and the perception that tourism benefits only those who are employed in tourism (mean 4.07).

Subsequently, the third group of hypotheses assumes the role of the political environment on tourism and how it is perceived by the community of Bled (H3a, H3b and $\mathrm{H} 3 \mathrm{c})$. The results confirm only the impact of the political environment on the socio-cultural (H3a, $\gamma=0.72, \mathrm{p}<0.001)$ and natural environment $(\mathrm{H} 3 \mathrm{~b}, \gamma=-0.14, \mathrm{p}<0.05)$, leaving the connection between the political and economic impact statistically non-significant (H3c).

Finally, in order to investigate the hypothesis of any indirect connections (H4a, H4b, and $\mathrm{H} 4 \mathrm{c}$ ) a mediation test was conducted (Figure 2). The results show that the relationship between the political environment and a resident's satisfaction with tourism is fully mediated by both their socio-cultural (H4a) and natural environments (H4b). However, it is the economic environment that again failed to meet our expectations and to prove that there is a mediating role between the political environment and a resident's satisfaction level (H4c). One could therefore argue that political governance can influence the satisfaction level of residents by improving their socio-cultural living conditions and the natural quality of their place of residence, but cannot affect it through the economic environment.

Indeed, this conflicts with our expectations that the empirical survey failed to prove a direct and indirect connection between the political and economic environment, as proposed in our theoretical model (Figure 1). Simply, from the local residents' viewpoint, the LTO, 
community strategy and residents do not directly affect the economic dimension of a destination.

In order to further understand the relationship between the political and economic environment in our proposed model, we studied the empirical findings of other possible connections (Figure 3). A possible impact of the political environment on the economic one via the natural environment was identified and confirmed (see Figure B in the Supplemental Data section available on the web based version of this paper.). In the case of Bled, the natural environment mediates the impact of the political environment on its economic environment. Obviously, the environmental impacts are a matter of consideration for the business world and for local tourism organisations and their community. The economic environment, or the tourism industry, has the power to create tourism development and growth. At the same time, the tourism industry has an interest in the use and consumption of the natural environment as natural resources attract visitors and constitute an integral part of the supply of tourism. When this happens, the community normally has a distributive power over its natural resources (Hall, 2000), such as the use of its environmental resources, waste management or water and air protection, urban planning etc. It is logical to expect that the two political and economic subjects will connect according to one common denominator. However, the question remains whether such collaboration is sufficient for tourism development to be sustainable for Bled. Sustainability implies a shift in power from those who traditionally had a major say in tourism development (the industry and its profit orientation) to all stakeholders of a destination. Thus, as already discussed in this paper, it demands the involvement of all of its stakeholders, a critical mass, consensus and collaborative action. In this context, it is safe to argue that the residents do not perceive tourism development in Bled as sustainable with regard to the existing economic environment. 
To summarise, it appears that Bled as a community and as a tourist destination requires the stronger engagement and collaboration of various organisations when it comes to effective tourism development and planning. Moreover, as one of the important stakeholders of the destination, residents acknowledged that, in order to be sustainable, tourism development should recognise and encourage a higher level of community satisfaction. This calls for a modification of the destination governance system in order to effectively develop and apply policies for tourism based on the coordination and cooperation of all of its stakeholders. This is in line with insights from previous tourism research (Bramwell, 2011; Bramwell \& Lane, 2011; Edgell, DelMastro Allen, Smith, \& Swanson, 2008) that challenge governance in the utilisation of resources and balance that with the needs of the host community and the tourism industry. Since most decisions within the tourism industry depend on private capital and private-public resource ownership, “...there are usually limits to the extent to which policies in the public sphere will influence commercial businesses and business decisions" (Bramwell, 2011, p. 461). In order to secure a higher level of coordination within the tourism industry itself, governance must overcome the obstacles of a fragmented industry that does not adequately represent weak interest groups (Williams \& Shaw, 1998), which usually tend to be made up of a community of local residents.

\section{Conclusion}

This study highlights the importance of the political environment in relation to sustainable tourism development. It responds to the absence of a comprehensive framework for the political dimension within the sustainability concept, as recognised by Ritchie and Crouch (2003), Mihalič (2009), and Mihalič et al. (2012). The study confirmed that the political environment, defined through some of the key features of governance, determines residents' 
perception of tourism impacts in relation to all three pillars of sustainability (economic, sociocultural and environmental). Consequently, residents' support for tourism can be influenced by a political environment and destination governance that are well developed.

With the above findings, the research also assists local community and governmental officials in understanding the importance of the political dimension in sustainable tourism development. According to the confirmed connections and impacts, the community of Bled has the potential to improve residents' satisfaction with tourism development by improving the dimensions of the political environment. In this regard, the following is recommended: to further develop support from local tourism organisations for tourism development (mean 2.95 on a scale of 1 to 7 ), to increase the involvement of local residents in tourism planning (mean 2.86) and to prioritise residents' interests when it comes to strategic development (mean 3.05). These actions will most certainly increase their satisfaction with tourism and support for tourism development.

A limitation of this study is the suggested list of indicators which were selected for the survey and confirmed by empirical evaluation in only one destination. First, the extensive literature research produced a list of over 200 possible indicators. Then a case-specific expert group was used to select the most appropriate indicators. Further data-reduction methodology, using data for one destination only, produced the final list. More specifically, different indicators might be appropriate for different destinations. In this regard, future research should also employ qualitative methods to further develop indicators, particularly for the political environment, which is the least developed in the literature.

Another limitation and probably contribution of this study is that, when we derived the political environment from the previous tourism research and analysed its meaning, we found that the existing understanding of political environment (Mihalič, 2009; Ritchie \& Crouch, 
2003) shares common points with the emerging concept of destination governance (Beritelli, 2011; Hall, 2011). This is not a surprise because a wider consensus on the meaning of the term political environment, as well as destination governance, among the tourism academic and research community has yet to be reached and future research will show how the terminology will develop. Despite the blurred relations between the political environment and governance, one of this study's contributions is to open up new horizons by adding a new dimension to the traditional sustainability model of three pillars when studying local residents' support for tourism development.

The proposed model may also serve as an antecedent for further research to ascertain whether the proposed extended model can be adapted and applied to other destinations in order to improve destination tourism governance and the implementation of sustainable tourism development.

\section{References}

Andereck, K. L., \& Vogt, C. A. (2000). The relationship between residents' attitudes toward tourism and tourism development options. Journal of Travel Research, 39(1), 27-36.

Andereck, K. L., Valentine, K. M., Knopf, R. C., \& Vogt, C. A. (2005). Residents' perceptions of community tourism impacts. Annals of Tourism Research, 32(4), 1056-1076.

Andereck, K., Valentine, K., Vogt, C. \& Knopf, R. (2007). A cross-cultural analysis of tourism and quality of life perceptions. Journal of Sustainable Tourism, 15(5), 483-502.

Baron, R. M., \& Kenny, D. A. (1986). The moderator-mediator variable distinction in social psychological research: Conceptual, strategic, and statistical considerations. Journal of Personality and Social Psychology, 51(6), 1173-1182.

Beritelli, P. T. (2011). Tourism destination governance through local entities - looking beyond the stakeholder level (Unpublished doctoral dissertation). University of St. Gallen, Switzerland. 
Boley, B. B., McGehee, N. G., Perdue, R. R., \& Long, P. (2014). Empowerment and resident attitudes toward tourism: Strengthening the theoretical foundation through a Weberian lens. Annals of Tourism Research, 49, 33-50.

Bramwell, B. (2011). Governance, the state and sustainable tourism: A political economy approach. Journal of Sustainable Tourism, 19(4-5), 459-477.

Bramwell, B., \& Lane, B. (2000).Collaboration in Tourism Planning, pp. 1-19 in Bramwell, B., \& Lane, B. (eds.) Tourism Collaborations and Partnerships: Politics, Practice and Sustainable Tourism, Clevedon, Channel View Publications.

Bramwell, B., \& Lane, B. (2011) Critical research on the governance of tourism and sustainability. Journal of Sustainable Tourism, 19(4-5) 411-421.

Brida, J. G., Disegna, M., \& Osti, L. (2011). Residents' perceptions of tourism impacts and attitudes towards tourism policies in a small mountain community. Benchmarking: An International Journal, 18(3), 359-385.

Bujosa Bestard, A., \& Rosselló Nadal, J. (2007a). Attitudes toward tourism and tourism congestion. Région et Développment, 25, 193-207. Retrieved on $25^{\text {th }}$ September, 2015 from: http://region-developpement.univ-tln.fr/fr/pdf/R25/Bujosa-Nadal.pdf

Bujosa Bestard, A., \& Rosselló Nadal, J. (2007b). Modelling environmental attitudes towards tourism. Tourism Management, 28(3), 688-695

Butler, R. (2010). Sustainability or stagnation? Limits, control, and the life cycle in tourist destinations. In E. Wickens \& M. Soteriades (Eds.), Sustainable tourism: Issues, debates and challenges. Conference proceedings (pp. 23-31). Crete: Technological Educational Institute of Greece.

Chen, J. S. (2001). Accessing and visualizing tourism impacts from urban residents' perspectives. Journal of Hospitality and Tourism Research, 25(3), 235-250.

Deery, M., Jago, L., \& Fredline, L. (2011). Rethinking social impacts of tourism research: A new research agenda. Tourism Management, 30(4), 1-10.

Doxey, G. V. (1975). A Causation Theory of Visitors-Residents Irritations: Methodology and Research Inferences, in Proceedings of the Travel Research Association, 1975, 6th Annual Conference, Salt Lake City, pp. 195-198.

Dyer, P., Gursoy, D., Sharma, B., \& Carter, J. (2007). Structural modelling of resident perceptions of tourism and associated development on the Sunshine Coast, Australia. Tourism Management, 28(2), 409-422. 
Eagles, P. F. J., McCool, S. F., \& Haynes, C. D. (2002). Sustainable tourism in protected areas: Guidelines for planning and management. Gland, Switzerland and Cambridge, UK: IUCN.

Easterling, D. (2004). The residents' perspective in tourism research: a review and synthesis. Journal of Travel and Tourism Marketing, 17(4), 45-62.

EC. (2014). European Tourism Indicators System Toolkit for sustainable destinations. European Commission. Retrieved on $25^{\text {th }}$ November, 2015 from http://ec.europa.eu/enterprise/sectors/tourism/sustainabletourism/indicators/index_en.htm

ECETAT \& ECOTRANS. (2004). The visit initiative: Tourism eco-labelling in Europe Moving the markets towards sustainability. Amsterdam: Authors.

Edgell, Sr, D. L., DelMastro Allen, M., Smith, G., \& Swanson, J. R. (2008). Tourism policy and planning: Yesterday, today and tomorrow. Amsterdam: Butterworth-Heinemann.

Gursoy, D., Jurowski, C., \& Uysal, M. (2002). Resident Attitudes: A Structural Modelling Approach. Annals of Tourism Research, 29, 79-105.

Gursoy, D., \& Rutherford, D.G. (2004). Host attitudes toward tourism: An improved structural model. Annals of Tourism Research, 31(3), 495-516.

Hair, J. F., Black, W. C., Babin, B. J., \& Anderson, R. E. (2010). Multivariate data analysis (7th ed.). Upper Saddle River, NJ: Prentice Hall.

Hall, D. (2000). Sustainable tourism development in Central and Eastern Europe. Journal of Sustainable Tourism, 8(6), 441-457.

Hall, C.M. (2008). Tourism planning. Policies, processes and relationships. Harlow: Pearson.

Hall, C.M. (2011). A typology of governance and its implications for tourism policy analysis. Journal of Sustainable Tourism, 19(4-5), 437-457.

Harrill, R. (2004). Residents' attitudes toward tourism development: A literature review with implications for tourism planning. Journal of Planning Literature 18(3), 215-266.

Higgins-Desbiolles, F. (2010). The Elusiveness of Sustainability in Tourism: The CultureIdeology of Consumerism and its Implications. Tourism and Hospitality Research, $10(2), 116-115$.

Jurowski, C., Uysal, M., \& Williams, D. R. (1997). A theoretical analysis of host community resident reactions to tourism. Journal of Travel Research, 36(2), 3-11.

Jurowski, C., \& Gursoy, D. (2004). Distance effects on residents' attitudes toward tourism. Annals of Tourism Research, 31(2), 296-312. 
Kenny, D. A., Kashy, D., \& Bolger, N. (1998). Data analysis in social psychology, pp. 233-265 in Gilbert D., Fiske, S. \& Lindzey G. (eds.) Handbook of social psychology, 4th ed. New York: McGraw-Hill.

Ko, D. W., \& Stewart, W. P. (2002). A structural equation model of residents' attitudes for tourism development. Tourism Management, 23(5), 521-530.

Lee, T. H. (2013). Influence analysis of community resident support for sustainable tourism development. Tourism Management, 34, 37-46.

Mihalič, T. (2009). Sodobna opredelitev razvoja in uspesnosti poslovanja [Modern definition of development and business performance]. In T. Mihalic (Ed.), Oblikovanje modela merjenja uspesnosti poslovanja hotelskih podjetij [Shaping the model for measuring hotel performance] (pp. 4-12). Ljubljana, Slovenia: RCEF.

Mihalič, T. (2016). Sustainable-responsible tourism discourse - Towards 'responsustable' tourism. Journal of Cleaner Production, 111, Part B, 461-470.

Mihalič, T., \& Kaspar, C. (1996). Umweltokonomie im Tourismus [Environmental Economics in Tourism]. Bern: Paul Haupt.

Mihalič, T., Žabkar, V., \& Knezević Cvelbar, L. (2012). A hotel sustainability business model: Evidence from Slovenia. Journal of Sustainable Tourism, 20(5), 701-719.

Municipality of Bled. (2009). Razvojni program občine Bled 2009-2020. [The development strategy of the Municipality of Bled 2009-2020]. Internal document: author.

Nunkoo, R., \& Ramkissoon, H. (2010). Small island urban tourism: A residents' perspective. Current Issues in Tourism, 13(1), 37-60.

Nunkoo, R., \& Ramkissoon, H. (2011). Developing a community support model for tourism. Annals of Tourism Research, 38(3), 964-988.

Nunkoo, R., \& Ramkissoon, H. (2012). Power, trust, social exchange and community support. Annals of Tourism Research, 39(2), 997-1023.

Nunkoo, R., Ramkissoon, H., \& Gursoy, D. (2012). Public trust in tourism institutions. Annals of Tourism Research, 39(3), 1538-1564.

Nunkoo, R., Smith, S., \& Ramkissoon, H. (2013). Resident attitudes to tourism: A longitudinal study of 140 articles from 1984 to 2010. Journal of Sustainable Tourism, 21(1), 5-25.

Perdue, R. R., Long, P. T., \& Kang, J. S. (1999). Boomtown Tourism and Resident Quality of Life: The Marketing of Gaming to Host Community Residence. Journal of Business Research, 44(3), 165-177.

Ritchie, B. J. R., \& Crouch, G. I. (2003). The competitive destination: A sustainable tourism perspective. Oxon (UK); Cambridge (MA): CABI Publishing. 
Sharpley, R. (2006). Travel and Tourism. London; Thousand Oaks; New Delhi: Sage Publications.

Sharpley, R. (2014). Host perceptions of tourism: A review of the research. Tourism Management, 42(1), 37-49.

SPIRIT Slovenia. (2014). Bled on the cover of Food and Travel and NG Traveller. Retrieved on $25^{\text {th }}$ June 2014 from: http://www.slovenia.info/si/news-items/Bled-on-the-Coverof-Food-and-Travel-and-NG-Traveller.htm?news_items=744\&lng=1.

SORS. (2014). Data. Statistical Office of the Republic of Slovenia. Retrieved on $25^{\text {th }}$ September, 2014 from http://www.stat.si/StatWeb/en/home. Stylidis, D., \& Terzidou, M. (2014). Tourism and the economic crisis in Kavala, Greece. Annals of Tourism Research, 44, 210-226.

Teye, V., Sirakaya, E., \& Sönmez, S. F. (2002). Residents' attitudes toward tourism development. Annals of Tourism Research, 29(3), 668-688.

Thibaut, J. W., \& Kelley, H. H. (1959). The Social Psychology of Groups. New York: John Wiley \& Sons.

UNEP \& WTO (2005). Making Tourism More Sustainable: A Guide for Policy Makers. Paris \& Madrid: United Nations Environmental Program \& United Nations World Tourism Organization.UNWTO. (2004). Indicators of sustainable development for tourism destinations: A guidebook. Madrid: United Nations World Tourism Organization.

Vargas-Sánchez, A., de los Ángeles Plaza-Mejía, M., \& Porras-Bueno, N., (2009). Understanding Residents' Attitudes toward the Development of Industrial Tourism in a Former Mining Community. Journal of Travel Research, 47(3), 373-387.

Vargas-Sánchez, A., Porras-Bueno, N., \& de los Ángeles Plaza-Mejía, M. (2011). Explaining residents' attitudes to tourism: Is a universal model possible? Annals of Tourism Research, 38(2), 460-480.

Wall, G., \& Mathieson, A. (2006). Tourism: Change, Impacts, and Opportunities. Essex, UK: Pearson Education Limited.

Wheeler, B. (1993). Sustaining the ego. Journal of Sustainable Tourism, 1(2), 121-129.

Williams, A., \& Shaw, G. (1998). Tourism and the environment: Sustainability and economic restructuring. In M. Hall \& A. Lew (Eds.), Sustainable tourism: A geographical perspective (pp. 49-59). Harlow: Longman.

Wrong, D. H. (1979). Power: Its Forms, Bases and Uses. Oxford: Blackwell.

Yoon, Y., Gursoy, D, \& Chen, J. S. (2001). Validating a tourism development theory with structural equation modelling. Tourism Management, 22(4), 363-372. 

Figure 1. Theoretical model, direct and indirect paths

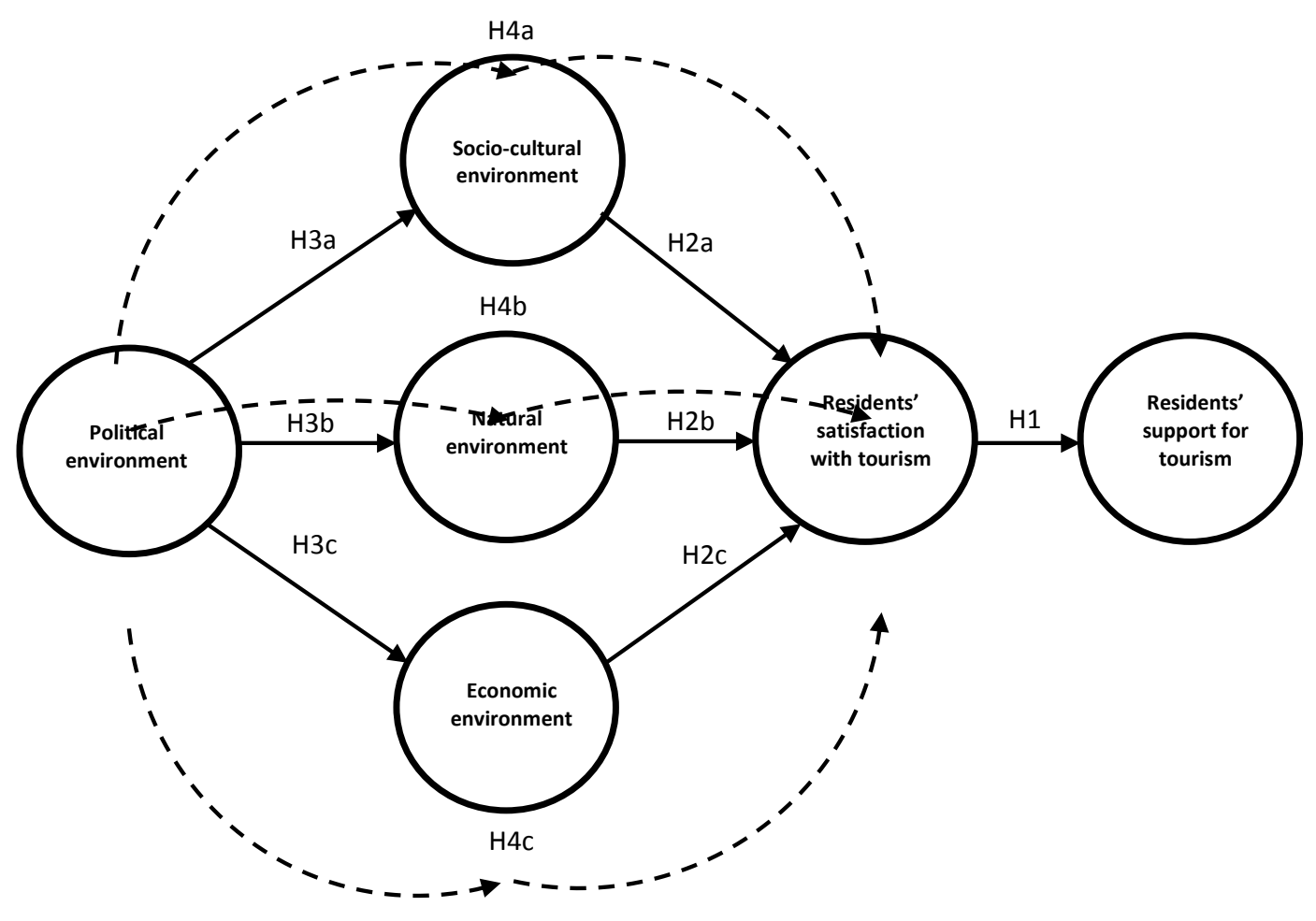

Direct path

Indirect path (Mediation effect) 
Figure 2. The model of residents' support for tourism

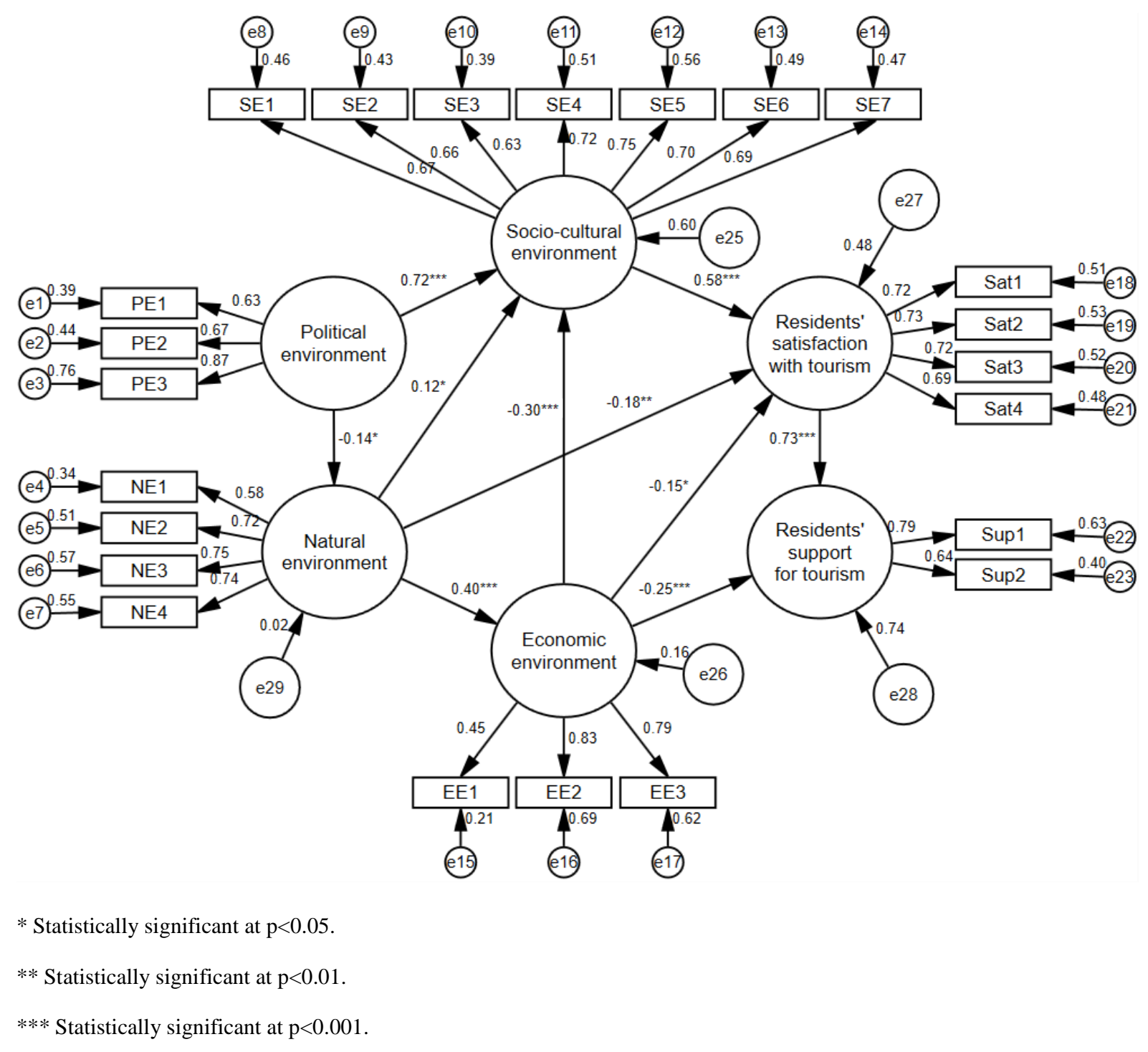

Goodness-of-fit measures: $\chi^{2}=663.141 ; \chi 2 / \mathrm{df}=3.001$; RMSEA $=0.078$; GFI $=0.848 ;$ AGFI $=0.810 ; \mathrm{CFI}=0.862 ; \mathrm{IFI}=$ 0.863 . 
Figure 3. Empirical model, mediation effects
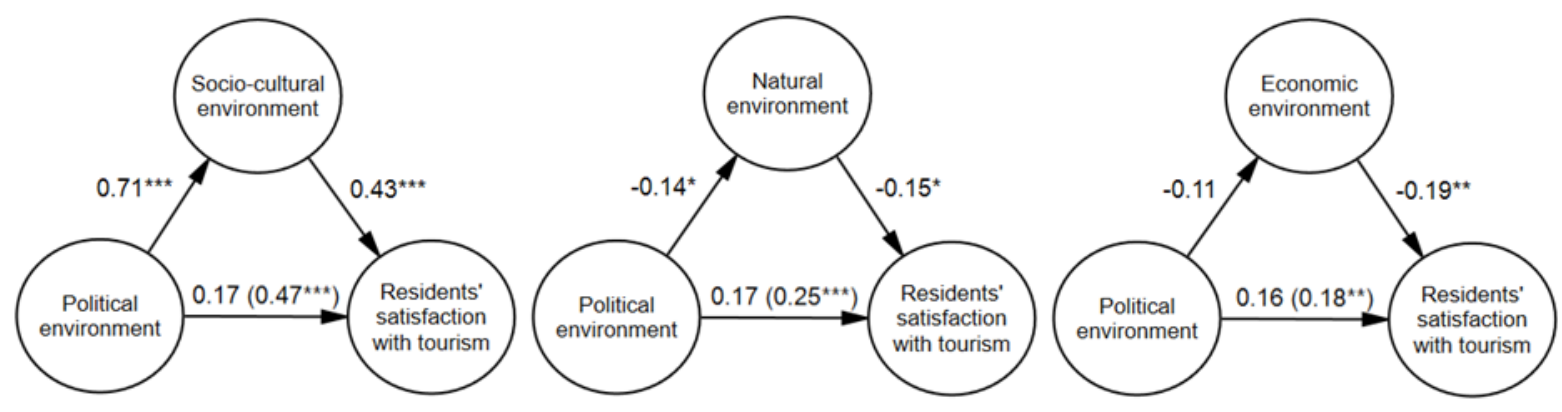

* Statistically significant at $\mathrm{p}<0.05$.

** Statistically significant at $\mathrm{p}<0.01$.

*** Statistically significant at $\mathrm{p}<0.001$.

The testing was conducted on the whole model, although only the parts of interest are represented in each figure. The number in parentheses represents the path when the mediator is not present. 
Table 1. Sample and representativeness tests

\begin{tabular}{|c|c|c|c|}
\hline Demographic characteristics & $\begin{array}{c}\text { Sample } \\
(\%)\end{array}$ & $\begin{array}{c}\text { Population } \\
(\%)\end{array}$ & Chi Square Test \\
\hline \multicolumn{4}{|l|}{ Age groups $(\%)$} \\
\hline -From 20 to 30 years & 18.00 & 15.50 & \multirow{5}{*}{$\chi^{2}=6.691, \mathrm{df}=4^{* *}$} \\
\hline -From 31 to 40 years & 21.10 & 18.80 & \\
\hline -From 41 to 50 years & 19.90 & 18.60 & \\
\hline -From 51 to 60 years & 15.50 & 17.30 & \\
\hline -From 61 to 84 years & 25.50 & 30.60 & \\
\hline \multicolumn{4}{|c|}{ Personal employment in tourism $(\%)^{*}$} \\
\hline -Yes & 23.10 & 22.50 & \multirow{2}{*}{$\chi 2=0.068, \mathrm{df}=1^{* *}$} \\
\hline - No & 76.90 & 77.50 & \\
\hline \multicolumn{4}{|c|}{ Location (residency within the Municipality) (\%) } \\
\hline - Bled & 66.80 & 63.50 & \multirow{5}{*}{$\chi^{2}=4.046, \mathrm{df}=4^{* *}$} \\
\hline - Zasip & 13.20 & 13.00 & \\
\hline - Bohinjska Bela & 5.80 & 6.70 & \\
\hline - Ribno & 5.20 & 7.80 & \\
\hline - Other & 9.00 & 9.00 & \\
\hline
\end{tabular}

* Percentages for population are given according to the number of active workforce in the Municipality.

$* *$ Significant at $\mathrm{p}>0.05$. 
Table 2. Descriptive statistics and measurement model results

\begin{tabular}{|c|c|c|c|c|c|c|c|c|c|}
\hline \multirow[b]{2}{*}{ Constructs and Indicators } & \multirow[b]{2}{*}{ Mean } & \multirow[b]{2}{*}{$\begin{array}{l}\text { St. } \\
\text { dev. }\end{array}$} & \multicolumn{3}{|c|}{ Responses in \% } & \multicolumn{4}{|c|}{ Measurement Model Results } \\
\hline & & & $\underset{*}{\text { Agree }}$ & $\begin{array}{c}\text { Disagree } \\
* *\end{array}$ & $\begin{array}{c}\text { Neutral } \\
* * *\end{array}$ & Loading & $\begin{array}{l}\text { Completely } \\
\text { Standardized } \\
\text { Loading }\end{array}$ & $P$ & $\begin{array}{l}\text { SMC and } \\
\text { Explained } \\
\text { Variance }\end{array}$ \\
\hline Political environment & 2.95 & & & & & & & & - \\
\hline $\begin{array}{l}\text { PE1_Tourism development in Bled is well } \\
\text { supported by its local tourism organization. }\end{array}$ & 2.95 & 1.73 & 19.20 & 63.30 & 17.60 & 0.74 & 0.63 & 0.00 & 0.39 \\
\hline $\begin{array}{l}\text { PE2_I am involved in the planning of } \\
\text { sustainable tourism in my community. }\end{array}$ & 2.86 & 1.81 & 21.40 & 63.80 & 14.90 & 0.82 & 0.67 & 0.00 & 0.44 \\
\hline $\begin{array}{l}\text { PE3_Community's quality of life is well } \\
\text { represented in development of sustainable } \\
\text { tourism in Bled. }\end{array}$ & 3.05 & 1.67 & 19.80 & 57.70 & 22.50 & 1.00 & 0.87 & & 0.76 \\
\hline Socio-cultural environment & 4.30 & & & & & & & & 0.60 \\
\hline $\begin{array}{l}\text { SE1_Tourism improves shopping, restaurant } \\
\text { and entertainment opportunities. }\end{array}$ & 3.64 & 2.04 & 38.90 & 48.00 & 13.10 & 1.00 & 0.67 & & 0.46 \\
\hline $\begin{array}{l}\text { SE2_Tourism is likely to provide more parks } \\
\text { and other recreational areas for locals. }\end{array}$ & 4.13 & 1.90 & 46.90 & 35.60 & 17.60 & 0.91 & 0.66 & 0.00 & 0.43 \\
\hline $\begin{array}{l}\text { SE3_Tourism encourages the production and } \\
\text { sales of local products. }\end{array}$ & 4.50 & 1.87 & 56.20 & 28.50 & 15.20 & 0.85 & 0.63 & 0.00 & 0.39 \\
\hline $\begin{array}{l}\text { SE4_Tourism is likely to provide more business } \\
\text { for local people and small businesses. }\end{array}$ & 4.80 & 1.83 & 63.00 & 22.50 & 14.60 & 0.95 & 0.72 & 0.00 & 0.51 \\
\hline $\begin{array}{l}\text { SE5_The quality of public services (fire } \\
\text { protection, police protection, public health } \\
\text { services, welfare and social services, etc.) in } \\
\text { Bled is better due to more tourism. }\end{array}$ & 4.45 & 1.82 & 54.40 & 29.20 & 16.40 & 1.00 & 0.75 & 0.00 & 0.56 \\
\hline $\begin{array}{l}\text { SE6_Tourism provides an incentive for the } \\
\text { preservation of local culture in Bled. }\end{array}$ & 4.57 & 1.82 & 61.70 & 25.50 & 12.80 & 0.93 & 0.70 & 0.00 & 0.49 \\
\hline $\begin{array}{l}\text { SE7_Tourism increases the quality of education } \\
\text { in Bled. }\end{array}$ & 4.07 & 1.79 & 46.50 & 36.50 & 17.00 & 0.90 & 0.69 & 0.00 & 0.47 \\
\hline Natural environment (negative impact) & 4.27 & & & & & & & & 0.02 \\
\hline NE1_Tourists pollute Bled with their waste. & 4.81 & 1.86 & 59.80 & 27.10 & 13.10 & 0.79 & 0.58 & 0.00 & 0.34 \\
\hline $\begin{array}{l}\text { NE2_Tourism development is likely to destroy } \\
\text { green areas in Bled. }\end{array}$ & 3.78 & 1.87 & 35.60 & 47.70 & 16.70 & 0.97 & 0.72 & 0.00 & 0.51 \\
\hline NE3_Tourism increases air pollution in Bled. & 3.72 & 1.91 & 40.80 & 47.40 & 11.90 & 1.04 & 0.75 & 0.00 & 0.57 \\
\hline $\begin{array}{l}\text { NE4_Tourism increases water pollution of lake } \\
\text { Bled. }\end{array}$ & 4.77 & 1.85 & 63.30 & 27.10 & 9.70 & 1.00 & 0.74 & & 0.55 \\
\hline Economic environment (negative impact) & 4.32 & & & & & & & & 0.16 \\
\hline $\begin{array}{l}\text { EE1_Tourism in Bled only benefits to those } \\
\text { employed in tourism. }\end{array}$ & 4.07 & 2.06 & 44.40 & 42.30 & 13.40 & 0.59 & 0.45 & 0.00 & 0.21 \\
\hline $\begin{array}{l}\text { EE2_Tourism hinders the development of other } \\
\text { economic industries in my community. }\end{array}$ & 4.04 & 2.00 & 45.60 & 38.60 & 15.80 & 1.06 & 0.83 & 0.00 & 0.69 \\
\hline $\begin{array}{l}\text { EE3_Bled is economically over-dependent } \\
\text { upon only one industry - tourism. }\end{array}$ & 4.84 & 2.01 & 62.00 & 24.90 & 13.10 & 1.00 & 0.79 & & 0.62 \\
\hline Residents' satisfaction with tourism & 5.72 & & & & & & & & 0.48 \\
\hline
\end{tabular}




\begin{tabular}{|c|c|c|c|c|c|c|c|c|c|}
\hline $\begin{array}{l}\text { SAT1_Because of tourism I would like to move } \\
\text { out of Bled.**** }\end{array}$ & 5.60 & 1.71 & 74.80 & 12.20 & 13.10 & 1.00 & 0.72 & & 0.51 \\
\hline $\begin{array}{l}\text { SAT2_I suffer from living in a tourism } \\
\text { destination.**** }\end{array}$ & 6.09 & 1.55 & 87.60 & 8.50 & 4.00 & 1.13 & 0.73 & 0.00 & 0.53 \\
\hline $\begin{array}{l}\text { SAT3_I'm proud to live in Bled, because it is a } \\
\text { well-known tourism destination. }\end{array}$ & 5.55 & 1.76 & 77.90 & 15.50 & 6.70 & 1.11 & 0.72 & 0.00 & 0.52 \\
\hline SAT4_I'm satisfied to live in Bled. & 5.66 & 1.63 & 79.10 & 13.10 & 7.90 & 0.98 & 0.69 & 0.00 & 0.48 \\
\hline Residents' support for tourism & 5.91 & & & & & & & & 0.74 \\
\hline $\begin{array}{l}\text { SUP1_I support tourism and its important } \\
\text { economic role in the community. }\end{array}$ & 6.19 & 1.31 & 90.90 & 5.40 & 3.60 & 1.00 & 0.79 & & 0.63 \\
\hline $\begin{array}{l}\text { SUP2_I support the development of tourism in } \\
\text { Bled over other industries. }\end{array}$ & 5.63 & 1.62 & 80.50 & 10.30 & 9.10 & 0.96 & 0.64 & 0.00 & 0.40 \\
\hline
\end{tabular}

* Agree: totally agree, agree and somehow agree.

** Disagree: totally disagree, disagree and somehow disagree.

*** Neutral: neither agree nor disagree.

**** The variables were reverse coded before CFA. The data thus represent the opposite meaning of the statements.

Figure A: Questionnaire on local residents' attitudes towards tourism, Bled

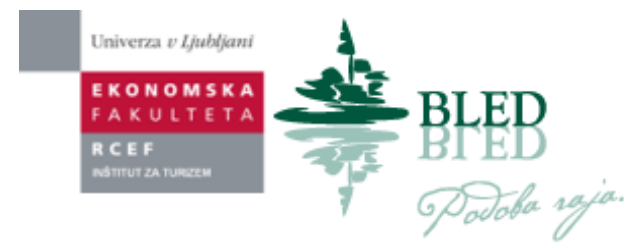

\section{LOCAL RESIDENTS' ATTITUDES TOWARDS TOURISM}

\section{QUESTIONNAIRE}

The questionnaire uses a 7-point Likert scale where: $1=\mathrm{I}$ totally disagree, $2=\mathrm{I}$ disagree, $3=\mathrm{I}$ somewhat disagree, 4 = I neither agree nor disagree, $5=\mathrm{I}$ somewhat agree, $6=\mathrm{I}$ agree, $7=\mathrm{I}$ totally agree.

1. Please indicate your level of agreement with the statements below:

\begin{tabular}{|l|c|c|c|c|c|c|c|}
\hline $\begin{array}{c}\text { I'm proud to live in Bled, because it is a well-known tourism } \\
\text { destination. }\end{array}$ & $\square$ & $\square$ & $\square$ & $\square$ & $\square$ & $\square$ & $\square$ \\
\hline $\begin{array}{c}\text { I support tourism and its important economic role in the } \\
\text { community. }\end{array}$ & $\square$ & $\square$ & $\square$ & $\square$ & $\square$ & $\square$ & $\square$ \\
\hline
\end{tabular}




\begin{tabular}{|c|c|c|c|c|c|c|c|c|}
\hline $\begin{array}{c}\text { In general, positive impacts of tourism in Bled outweigh the } \\
\text { negative ones. }\end{array}$ & $\square$ & $\square$ & $\square$ & $\square$ & $\square$ & $\square$ & $\square$ \\
\hline $\begin{array}{c}\text { Bled needs more tourist facilities (hotels, restaurants, sports } \\
\text { facilities, etc.). }\end{array}$ & $\square$ & $\square$ & $\square$ & $\square$ & $\square$ & $\square$ & $\square$ \\
\hline $\begin{array}{c}\text { Tourism development in Bled is well supported by its local } \\
\text { tourism organization. }\end{array}$ & $\square$ & $\square$ & $\square$ & $\square$ & $\square$ & $\square$ & $\square$ \\
\hline $\begin{array}{c}\text { I support the development of tourism in Bled over other } \\
\text { industries. }\end{array}$ & $\square$ & $\square$ & $\square$ & $\square$ & $\square$ & $\square$ & $\square$ \\
\hline $\begin{array}{c}\text { Tourism in Bled only benefits those employed in tourism. } \\
\begin{array}{c}\text { The municipality should have more benefits from tourism in } \\
\text { Bled. }\end{array}\end{array}$ & $\square$ & $\square$ & $\square$ & $\square$ & $\square$ & $\square$ & $\square$ \\
\hline
\end{tabular}

2. How do you feel as a citizen of Bled?

\begin{tabular}{|c|c|c|c|c|c|c|c|}
\hline & 1 & 2 & 3 & 4 & 5 & 6 & 7 \\
\hline I'm satisfied to live in Bled. & $\square$ & & L & & 1 & & \\
\hline Tourism development influences my personal growth. & & & $\square$ & & & & \\
\hline Tourism development contributes to quality of life in Bled & & & $\square$ & & & & \\
\hline I suffer from living in a tourism destination. & & & & & & & \\
\hline Because of tourism I would like to move out of Bled. & & & & & & & \\
\hline I'm satisfied with recreational opportunities in Bled. & & & & & & & \\
\hline I'm satisfied with my life in general. & & & & & & & \\
\hline $\begin{array}{l}\text { I am involved in the planning of sustainable tourism in my } \\
\text { community. }\end{array}$ & & & $\square$ & & 71 & 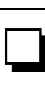 & \\
\hline I'm well informed about tourism development in Bled. & & & & & & 7 & \\
\hline $\begin{array}{c}\text { The community's quality of life is well represented in } \\
\text { development of sustainable tourism in Bled. }\end{array}$ & $\square$ & & $\square$ & & 7 & $\square$ & \\
\hline
\end{tabular}


3. Please indicate the level of agreement with the statements below:

\begin{tabular}{|c|c|c|c|c|c|c|c|}
\hline & 1 & 2 & 3 & 4 & 5 & 6 & 7 \\
\hline Tourism preserves the environment in Bled. & t & 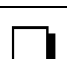 & $\square$ & 7 & & & \\
\hline $\begin{array}{c}\text { Tourism improves the appearance (and images) of Bled's } \\
\text { landscape. }\end{array}$ & $\square$ & $\square$ & $\square$ & 7 & & & \\
\hline Tourists pollute Bled with their waste. & ] & & & 7 & & & \\
\hline Tourism increases air pollution in Bled. & $\square$ & & & & & & \\
\hline Tourism increases water pollution of Lake Bled. & $\square$ & & & & & & \\
\hline Tourism development is likely to destroy green areas in Bled. & $\square$ & & & & & & \\
\hline $\begin{array}{l}\text { Tourism decreases the availability of publicly accessible utilities } \\
\text { in Bled. }\end{array}$ & & & & & & & \\
\hline Tourism development increases traffic congestion in Bled. & & & & & & & \\
\hline $\begin{array}{c}\text { Tourism provides an incentive for the preservation of local } \\
\text { culture in Bled. }\end{array}$ & & & & & & & \\
\hline Because of tourism, the Bled island is over-commercialized. & 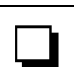 & & & & & & \\
\hline Tourism is likely to increase crime rate in my community. & & & & & & & \\
\hline $\begin{array}{l}\text { The quality of public services (fire protection, police protection, } \\
\text { public health services, welfare and social services, etc.) in Bled is } \\
\text { better due to more tourism. }\end{array}$ & & & & & & & \\
\hline Tourism increases the quality of education in Bled. & & & & & & & \\
\hline $\begin{array}{l}\text { Tourism is likely to provide more business for local people and } \\
\text { small businesses. }\end{array}$ & $\Gamma$ & & & & & & \\
\hline $\begin{array}{c}\text { Tourism improves shopping, restaurant and entertainment } \\
\text { opportunities. }\end{array}$ & Г & & & & & & \\
\hline Tourism in Bled results in crowding. & $\square$ & $\Gamma$ & & 7 & & & \\
\hline $\begin{array}{c}\text { Tourism is likely to provide more parks and other recreational } \\
\text { areas for locals. }\end{array}$ & $\square$ & г & & & & & \\
\hline $\begin{array}{c}\text { Increasing the number of tourists is likely to result in conflicts } \\
\text { between visitors and residents. }\end{array}$ & $\square$ & $\square$ & $\Pi$ & $\square$ & $\square$ & & \\
\hline
\end{tabular}




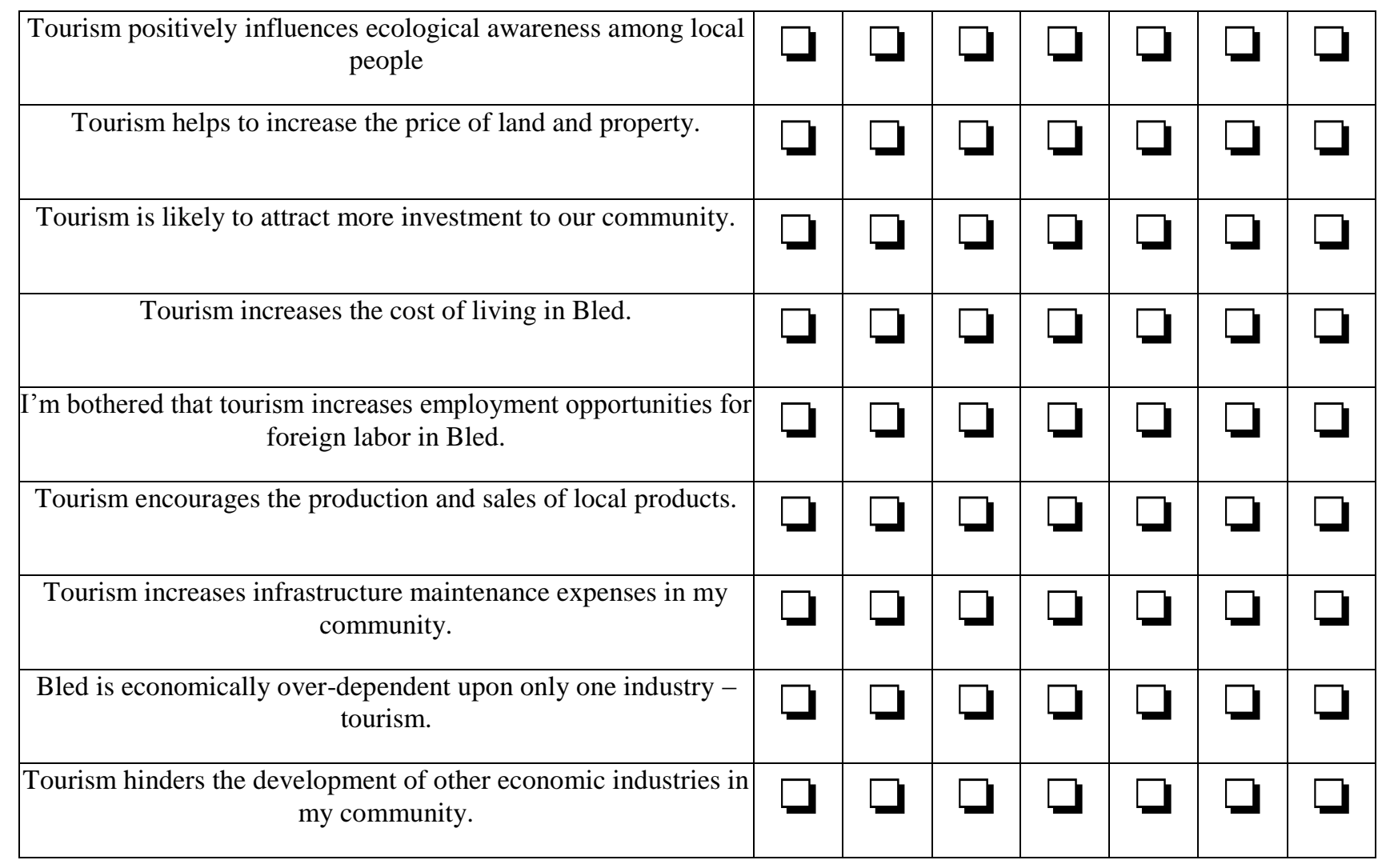

4. Please evaluate proposed statements about current tourism capacities:

\begin{tabular}{|c|c|c|c|c|c|c|c|c|}
\hline & 1 & 2 & 3 & 4 & 5 & 6 & 7 \\
\hline The number of tourists visiting Bled should increase annually. & $\square$ & $\square$ & $\square$ & $\square$ & $\square$ & $\square$ & $\square$ \\
\hline The number of tourists in Bled is excessive in summer period. & $\square$ & $\square$ & $\square$ & $\square$ & $\square$ & $\square$ & $\square$ \\
\hline The number of one-day visitors in Bled should decrease. & $\square$ & $\square$ & $\square$ & $\square$ & $\square$ & $\square$ & $\square$ \\
\hline The number of overnight stays in Bled should increase annually. & $\square$ & $\square$ & $\square$ & $\square$ & $\square$ & $\square$ & $\square$ \\
\hline
\end{tabular}

5. Please, evaluate your knowledge about tourism and its development:

\begin{tabular}{|c|c|c|c|c|c|c|c|}
\hline & 1 & 2 & 3 & 4 & 5 & 6 & 7 \\
\hline I have lots of knowledge about tourism. & $\square$ & $\square$ & $\square$ & $\square$ & $\square$ & $\square$ & $\square$ \\
\hline
\end{tabular}


6. Gender:

1. Male

2. Female

7. Are you employed in tourism in Bled?

1. Yes

2. No

8. Is anybody from your family employed in tourism in Bled?

3. Yes

4. No

9. Does your household have any economic benefit from tourism in Bled (e.g. room rentals, product sales etc.)?

5. Yes

6. No

10. Where in Bled do you live?
1. Bled
2. Bodešče
3. Bohinjska Bela
4. Koritno
5. Kupljenik
6. Obrne
7. Ribno
8. Selo pri Bledu
9. Slamniki
10. Zasip 
11. How many years have you been living in Bled? (Please, write the number.)

12. How old are you? (Please, write the number.)

13. What is the highest level of education you have finished?
1. Elementary school
2. High school
3. Technical, vocational or commercial school
4. Bachelor degree school
5. Master degree school
6. Doctoral school

14. What is the net monthly income of your household?
1. Less than 1000 EUR
2. Between 1001 EUR and 2000 EUR
3. Between 2001 EUR and 3000 EUR
4. Between 3001 EUR and 4000 EUR
5. Between 4001 EUR and 5000 EUR
6. More than 5001 EUR

15. How many members are in your household? (Please, write the number.) 
16. Please write any additional opinion about your attitude towards tourism in Bled or your willingness to actively participate in the strategic development of tourism in Bled.

THANK YOU FOR YOUR COOPERATION!

Institute for Tourism, Faculty of Economics, University of Ljubljana

Turizem Bled 